\title{
STRATEGI PENINGKATAN PREDIKAT DAERAH TERTINGGAL DI KABUPATEN PANDEGLANG PROVINSI BANTEN
}

\author{
Ardiyansah $^{1}$ \\ ${ }^{1}$ Program Studi Manajemen, STIE Al-Khairiyah Cilegon
}

\begin{abstract}
The Village Fund allocation which is given directly to the village government is expected to be able to increase the income of the village community, not only improve the quality of human life, but also increase the income of the village community. The problem of disadvantaged areas is not only the focus of attention of the Central Government but also the Provincial Government. The designation of Pandeglang Regency as a disadvantaged area can be seen from several aspects including regional financial revenue, Human Development Index and the level of the people's economy which is indicated through the unemployment rate of Pandeglang people and the comparison of the number of poor people in regencies and cities throughout Banten Province. This study aims to know how the Pandeglang Regency strategy in improving the predicate of disadvantaged areas. Several improvements have been made in various sectors to improve the predicate of disadvantaged areas in Pandeglang Regency, among others, by implementing a strategy of efficient use of the budget through trimming several programs whose impact on increasing the increase in SAKIP assessments annually. The strategy paid off with an increase in SAKIP assessments that had an impact on increasing the predicate of disadvantaged areas. In addition Pandeglang Regency has also carried out an economic development scheme in increasing the predicate of disadvantaged areas through a scheme initiated by the Ministry of PDT, namely by Transportation from Farmers, Ports and Consumers, Smart Farming Scheme, and Data Collection Scheme Number of fruit trees in disadvantaged areas.
\end{abstract}

Keywords: Strategy, Increasing the Predicate of Disadvantaged Areas, Pandeglang Regency

\section{Pengantar}

Negara Indonesia sebagai negara yang berdasar atas hukum memiliki beberapa tujuan penyelenggaraan negara, sebagaimana diamanatkan dalam Pembukaan Undang-Undang Dasar Negara Republik Indonesia Tahun 1945 (selanjutnya disebut UUD 1945). Tujuan negara Indonesia antara lain adalah untuk melindungi segenap bangsa dan seluruh tumpah darah Indonesia, memajukan kesejahteraan umum, mencerdaskan kehidupan bangsa, dan ikut melaksanakan ketertiban dunia yang berdasarkan kemerdekaan, perdamaian abadi dan keadilan sosial. Konsep tujuan negara yang tidak hanya sebagai negara formal untuk menjaga keamanan dan ketertiban masyarakat melainkan pula berkewajiban meningkatkan kesejahteraan warga negaranya. Mencapai kesejahteraan umum rakyat Indonesia bukan suatu hal yang mudah, terlebih lagi kondisi geografis Indonesia sebagai negara 
Kepulauan yang sangat luas, menjadikan Pemerintah Indonesia sulit menyelenggarakan pemerintahan yang bersifat sentralistik. Berbagai upaya telah dilakukan Pemerintah Indonesia dalam rangka meningkatkan kesejahteraan umum rakyatnya, salah satunya adalah dengan menerapkan konsep otonomi desa yang diartikan sebagai kewenangan bagi pemerintah desa untuk mengurus kepentingan masyarakat setempat (desa) berdasarkan asal usul dan adat istiadat setempat yang diakui dan dihormati dan berperan dalam mewujudkan cita-cita kemerdekaan Indonesia. Berdasarkan hal tersebut maka pemerintah desa memiliki wewenang dan tanggung jawab terhadap peningkatan kesejahteraan masyarakat desa.

Indonesia telah melaksanakan berbagai program peningkatan kesejahteraan masyarakat dan kedaulatan politik yang terangkum melalui program Nawacita. Program ini digagas untuk menunjukkan prioritas jalan perubahan menuju Indonesia yang berdaulat secara politik, serta mandiri dalam bidang ekonomi dan berkepribadian dalam kebudayaan. Salah satu program nawacita yang didasari atas peningkatan kesejahteraan masyarakat desa adalah membangun Indonesia dari pinggiran dengan memperkuat daerah-daerah dan desa dalam kerangka negara kesatuan. Bentuk komitmen pemerintah Indonesia dalam meningkatkan kesejahteraan desa adalah dengan mengalokasikan dana desa. Tahun 2016 pemerintah Indonesia mengalokasikan dana desa sebesar Rp. 46,9 Triliun dan pada tahun 2017 meningkat menjadi Rp. 60 Triliun (www.kominfo.go.id, 2019).
Alokasi Dana Desa yang
diberikan pemerintah desa diharapkan mampu meningkatkan pendapatan masyarakat desa, bukan hanya meningkatkan kualitas hidup manusia, tetapi juga meningkatkan pendapatan masyarakat desa tersebut. Menurut Menteri Desa, Pembangunan Daerah Tertinggal dan Transmigrasi, dana desa yang telah diberikan kemudian dikembangkan melalui pengembangan Produk Unggulan/Produk Unggulan Kawasan Pedesaan (Prudes/Prukades). Dana desa tidak hanya difokuskan untuk program ekonomi saja melainkan juga pembangunan infrastruktur, meningkatkan kualitas pelayanan publik dan juga memberantas gangguan pertumbuhan anak-anak di desa akibat stunting. Dalam Peraturan Menteri Desa telah diatur mengenai mekanisme pengalokasian Dana Desa bagi BUMDes sesuai dengan tipologi masing-masing desa yang dinilai berdasarkan Indeks Desa Membangun (IDM) yaitu: Desa Maju/Mandiri, Berkembang dan Tertinggal.

Penetapan Daerah Tertinggal di Indonesia ditetapkan melalui Peraturan Presiden Republik Indonesia Nomor 131 Tahun 2015. Berdasarkan Perpres tersebut ada sekitar 122 Kabupaten di Indonesia yang ditetapkan sebagai daerah tertinggal, salah satunya adalah Kabupaten Pandeglang. Kabupaten Pandeglang merupakan salah satu daerah di Provinsi Banten yang ditetapkan sebagai daerah tertinggal. Daerah Tertinggal adalah daerah kabupaten yang wilayah serta masyarakatnya kurang berkembang dibandingkan dengan daerah lain dalam skala nasional. Suatu daerah 
ditetapkan sebagai Daerah Tertinggal berdasarkan kriteria sebagai berikut:

a. Perekonomian masyarakat;

b. Sumber daya manusia;

c. Sarana dan prasarana;

d. Kemampuan keuangan daerah

e. Aksebilitasdan Karakteristik daerah (Peraturan Presiden RI Nomor 131, 2015).

Adanya disparitas kualitas sumberdaya manusia antarwilayah, perbedaan kemampuan perekonomian antar daerah, serta belum meratanya ketersediaan infrastruktur antarwilayah mendukung fakta kesenjangan antar wilayah. Dengan memperhatikan isu strategis pembangunan daerah tertinggal dan sasaran tertinggal, arah kebijakan pembangunan daerah tertinggal difokuskan pada:

(a) Promosi potensi daerah tertinggal untuk mempercepat pembangunan, sehingga terbangun kemitraan dengan banyak pihak. Promosi daerah tertinggal ini juga akan mendorong masyarakat semakin mengetahui potensi daerah tersebut dan aktif dalam membantu pembangunan;

(b) Upaya pemenuhan kebutuhan dasar dan kebutuhan pelayanan dasar publik;

(c) Pengembangan perekonomian masyarakat yang didukung oleh manusia yang berkualitas dan infrastruktur penunjang konektivitas antar daerah tertinggal dan kawasan strategis.

Persoalan daerah tertinggal bukan hanya menjadi fokus perhatian Pemerintah Pusat tetapi juga Pemerintah Provinsi. Pemerintah Provinsi Banten telah memberikan perhatian lebih kepada daerah yang ditetapkan sebagai daerah tertinggal. Pada tahun 2018 Kabupaten Pandeglang menerima bantuan keuangan dari pemerintah provinsi sebesar Rp. 65 Miliar. Dana yang diberikan digunakan untuk pembangunan infrastruktur guna mengejar ketertinggalan. Penetapan Kabupaten Pandeglang sebagai daerah tertinggal dapat dilihat dari beberapa aspek diantaranya penerimaan keuangan daerah, Indeks Pembangunan Manusia dan tingkat perekonomian masyarakat yang ditunjukan melalui tingkat pengangguran masyarakat Pandeglang dan perbandingan jumlah penduduk miskin yang ada di kabupaten dan kota se-Provinsi Banten.

Dilihat dari aspek penerimaan keuangan, Kabupaten Pandeglang masih mengandalkan penerimaan dari pemerintah pusat dan pemerintah provinsi diantaranya adalah melalui dana perimbangan, dana lainnya dan transfer pemerintah provinsi. Sedangkan Pendapatan Asli Daerah Kabupaten Pandeglang sendiri masih sangat kecil bila dibandingkan dengan penerimaan pada sektor transfer pemerintah pusat dan pemerintah provinsi. PAD Kabupaten Pandeglang tahun 2017 hanya sekitar Rp. 235.417.305.349,atau hanya 10 persen dari total penerimaan Kabupaten Pandeglang. Hal tersebut dijelaskan melalui tabel 1: 
Tabel 1

Realisasi Penerimaan Kabupaten Pandeglang Menurut Jenis Pendapatan tahun 2017

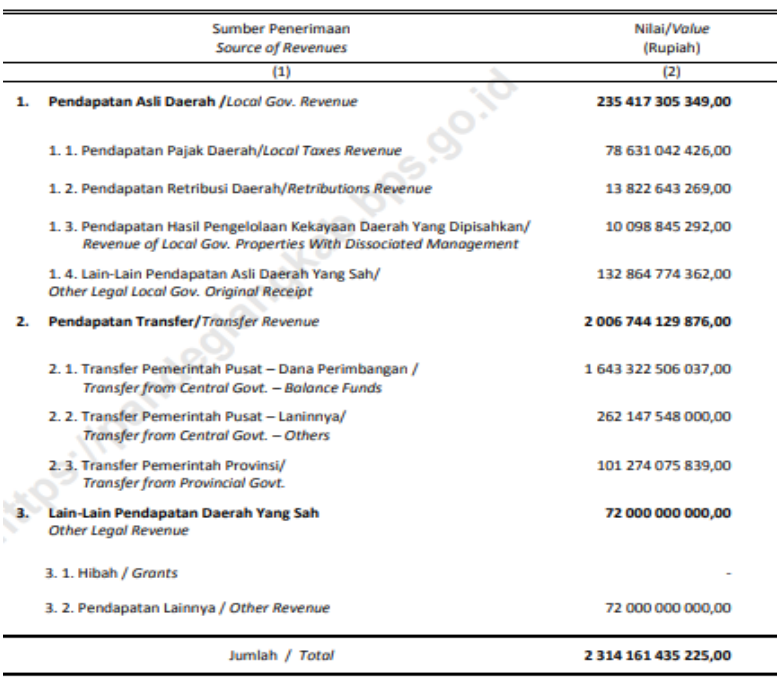

Berdasarkan tabel diatas diketahui bahwa total penerimaan Kabupaten Pandeglang lebih banyak bersumber dari bantuan pemerintah pusat dan pemerintah provinsi atau sekitar 86,72 persen dari total penerimaan Kabupaten Pandeglang. Sisanya sekitar 3,1 persen bersumber dari pendapatan lain yang sah seperti Hibah dan lain-lain. Hal tersebut dijelaskan melalui bagan dibawah ini:

\section{Bagan 1. Realisasi PAD Pandeglang}

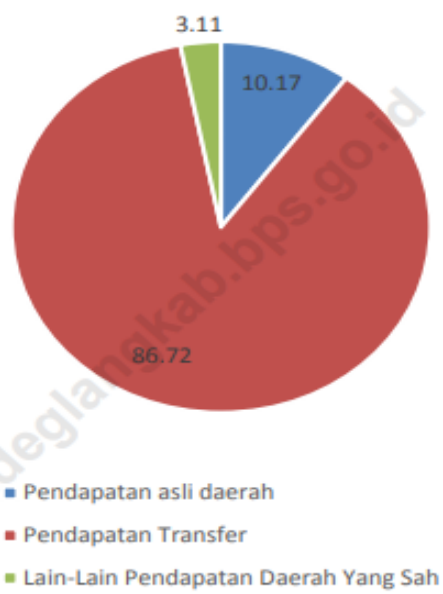

Dilihat dari aspek Indeks Pembangunan Manusia (IPM), tahun
2017 IPM Kabupaten Pandeglang dan Kabupaten Lebak merupakan IPM terendah diantara kabupaten dan kota lainnya di Provinsi Banten. berdasarkan data Badan Pusat Statistik (BPS) Pandeglang dalam rentang empat tahun terakhir, IPM Pandeglang tercatat kemajuannya sangat lamban. Pada 2013, IPM tercatat 61.35, kemudian tahun 2014 naik menjadi 62.06, tahun 2015 naik menjadi 62.72, tahun 2016 naik menjadi 63.40 dan kemudian tahun 2017 naik menjadi 63.82. Hal tersebut dijelaskan melalui tabel 2:

Tabel. 2

Indeks Pembanguanan Manusia (IPM) Menurut Kabupaten/Kota di Provinsi Banten Tahun 2013-2017

\begin{tabular}{lccccc}
\hline \hline $\begin{array}{c}\text { Kabupaten/Kota } \\
\text { Regency/Municipality }\end{array}$ & $\mathbf{2 0 1 3}$ & $\mathbf{2 0 1 4}$ & $\mathbf{2 0 1 5}$ & $\mathbf{2 0 1 6}$ & $\mathbf{2 0 1 7}$ \\
\hline \multicolumn{1}{c}{$(1)$} & $(2)$ & $(3)$ & $(4)$ & $(5)$ & $(6)$ \\
\hline Kabupaten/Regency & & & & & \\
1. Pandeglang & 61,35 & 62,06 & 62,72 & 63,40 & 63.82 \\
2. $\quad$ Lebak & 61,13 & 61,64 & 62,03 & 62,78 & 62.95 \\
3. Tangerang & 69,28 & 69,57 & 70,05 & 70,44 & 70.97 \\
4. $\quad$ Serang & 63,57 & 63,97 & 64,61 & 65,12 & 65.60
\end{tabular}

\begin{tabular}{|c|c|c|c|c|c|c|}
\hline 1. & Tangerang & 75,04 & 75,87 & 76,08 & 76,81 & 77.0 \\
\hline 2 & Clepon & 7099 & 7157 & 7181 & 7204 & 72.2 \\
\hline 3. & Serang & 69,69 & 70,26 & 70,51 & 71,09 & 71.3 \\
\hline 4. & Tangerang Selatan & 78,65 & 79,17 & 79.38 & 80.11 & 80.8 \\
\hline & Banten & 69.47 & 6989 & 7027 & 7096 & 714 \\
\hline
\end{tabular}

perekonomian masyarakat melalui angka pengangguran di Kabupaten Pandeglang, Berdasarkan Data Dinas Tenaga Kerja dan Transmigrasi (Disnakertrans) Kabupaten Pandeglang tingkat pengangguran di Kabupaten Pandeglang tahun 2018 sebanyak 8,2\% atau 68.041 orang yang terdiri dari laki-laki sebanyak 34.644 orang dan perempuan sebanyak $33.397 \quad$ orang (bantennews.com). Berdasarkan hal tersebut Kabupaten Pandeglang 
menjadi salah satu daerah penyumbang angka pengangguran di Provinsi Banten. Persoalan tersebut dipengaruhi oleh rata-rata lama sekolah penduduk di Kabupaten Pandeglang. Hal ini dijelaskan melalui tabel 3:

Tabel 3

Rata-Rata Lama Sekolah Menurut Kabupaten/Kota di Provinsi Banten Tahun 2013-2017

\begin{tabular}{|c|c|c|c|c|c|c|}
\hline & $\begin{array}{l}\text { Kabupaten/Kota } \\
\text { gency/Municipality }\end{array}$ & 2013 & 2014 & 2015 & 2016 & 2017 \\
\hline & (1) & (2) & (3) & (4) & (5) & (6) \\
\hline \multicolumn{7}{|c|}{ Kabupaten/Regency } \\
\hline 1. & Pandeglang & 6,44 & 6,45 & 6,60 & 6,62 & 6.63 \\
\hline 2. & Lebak & 5,81 & 5,84 & 5,86 & 6,19 & 6.20 \\
\hline 3. & Tangerang & 8,18 & 8,20 & 8,22 & 8,23 & 8.24 \\
\hline 4. & Serang & 6,65 & 6,69 & 6,90 & 6,98 & 7.17 \\
\hline \multicolumn{7}{|c|}{ Kota/City } \\
\hline & Tangerang & 9,82 & 10,20 & 10,20 & 10,28 & 10.29 \\
\hline 2. & Cilegon & 9,60 & 9,66 & 9,67 & 9,68 & 9.69 \\
\hline 3. & Serang & 8,56 & 8,58 & 8,59 & 8,60 & 8.61 \\
\hline 4. & Tangerang Selatan & 11,48 & 11,56 & 11,57 & 11,58 & 11.77 \\
\hline & Banten & 8,17 & 8,19 & 8,27 & 8,37 & 8.53 \\
\hline
\end{tabular}

Berdasarkan data diatas

diketahui bahwa angka rata-rata lama sekolah di Kabupaten Pandeglang berada diangka 6,63 diatas Kabupaten Lebak yang berada diangka 6,20, namun berada dibawah kabpuaten/kota lainnya di Provinsi Banten. Angka rata-rata lama sekolah di Kabupaten Pandeglang juga berkaitan dengan jumlah angka kemiskinan di Kabupten Pandeglang. Berdasarkan data angka kemiskinan penduduk Kabupaten Pandeglang berada diurutan kedua dengan jumlah sekitar 117.000 orang setelah Kabupaten Tangerang dengan jumlah 190.000 orang. Hal tersebut dijelaskan melalui tabel dibawah ini:
Tabel 4

Tabel Jumlah Penduduk Miskin Menurut Kabupaten/Kota di Provinsi Banten (Ribu Orang) Tahun 2013-2017

\begin{tabular}{|c|c|c|c|c|c|}
\hline $\begin{array}{c}\text { Kabupaten/Kota } \\
\text { Regency/Municipality }\end{array}$ & 2013 & 2014 & 2015 & 2016 & 2017 \\
\hline (1) & (2) & (3) & (4) & (5) & (6) \\
\hline \multicolumn{6}{|l|}{ Kabupaten/Regency } \\
\hline 1. Pandeglang & 121,15 & 113,14 & 124,42 & 115,90 & 117,31 \\
\hline 2. Lebak & 118,56 & 115,83 & 126,42 & 111,21 & 111,08 \\
\hline 3. Tangerang & 183,89 & 173,10 & 191,12 & 182,52 & 191,62 \\
\hline 4. Serang & 72,81 & 71,38 & 74,85 & 67,92 & 69,10 \\
\hline \multicolumn{6}{|l|}{ Kota/City } \\
\hline 1. Tangerang & 103,07 & 98,76 & 102,56 & 102,88 & 105,34 \\
\hline 2. Cilegon & 15,93 & 15,53 & 16,96 & 14,90 & 14,89 \\
\hline 3. Serang & 36,75 & 36,18 & 40,19 & 36,40 & 36,97 \\
\hline 4. Tangerang Selatan & 25,36 & 25,29 & 25,89 & 26,38 & 28,73 \\
\hline Banten & 642,88 & 677,51 & 649,19 & 658,11 & 675,04 \\
\hline
\end{tabular}

Melihat dari beberapa aspek yang dijelaskan sebelumnya, Pemerintah Kabupaten Pandeglang terus berupaya untuk membenahi berbagai sektor agar mampu terlepas dari predikat daerah tertinggal. Berdasarkan data lain dijelaskan sekitar 70 dari 326 desa yang ada di Kabupaten Pandeglang masih tertinggal, dan Pemerintah Kabupaten Pandeglang setiap tahun memprogramkan untuk mengeluarkan 12 desa dari ketertinggalan menjadi desa maju (www.pelitabanten.com, n.d.). Berdasarkan data tersebut maka penelitian ini bertujuan mengatahui bagaimana strategi Kabupaten Pandeglang dalam meningkatkan predikat daerah tertinggal.

\section{Landasan Teori}

Strategi merupakan hal penting bagi kelangsungan hidup dari suatu perusahan untuk mencapai sasaran atau tujuan perusahaan yang efektif dan efisien, perusahaan harus bisa menghadapi setiap masalahmasalah atau hambatan yang datang dari dalam perusahaan maupun dari luar perusahaan. Strategi merupakan 
alat untuk mencapai tujuan, dalam pengembangannya konsep mengenai strategi harus terus memiliki perkembangan dan setiap orang mempunyai pendapat atau definisi yang berbeda mengenai strategi. Strategi dalam suatu dunia bisnis atau usaha sangatlah di butuhkan untuk pencapaian visi dan misi yang sudah di terapkan oleh perusahaan, maupun untuk pencapaian sasaran atau tujuan, baik tujuan jangka pendek maupun tujuan jangka panjang.

Strategi adalah sarana bersama dengan tujuan jangka panjang yang hendak dicapai. Strategi bisnis mencakup ekspansi georafis, diversifikasi, akusisi, pengembangan produk, penetrasi pasar, pengetatan, divestasi, likuidasi, dan usaha patungan atau joint venture (David, 2011). Strategi adalah aksi potensial yang membutuhkan keputusan manajemen puncak dan sumber daya perusahaan dalam jumlah besar. Jadi strategi adalah sebuah tindakan aksi atau kegiatan yang dilakukan oleh seseorang atau perusahaan untuk mencapai sasaran atau tujuan yang ditetapkan.

Istilah strategi berasal dari bahasa Yunani yaitu strategia yang artinya seni atau ilmu untuk menjadi seorang jendral. Strategi juga bisa diartikan suatu rencana untuk pembagian dan penggunaan kekuatan militer pada daerah - daerah tertentu untuk mencapai tujuan tertentu (Tjiptono, 2006). Sedangkan strategi adalah rencana berskala besar, dengan orientasi masa depan, guna berinteraksi dengan kondisi persaingan untuk mencapai tujuan perusahaan (Pearce II, Jhon A and Robinson Richard B, 2008).

Dari definisi tersebut, dapat disimpulkan bahwa pengertian dari
Strategi adalah sebuah tindakan proses perencanaan untuk mencapai tujuan yang telah ditetapkan, dengan melalukan hal-hal yang besifat terus menerus sesuai keputusan bersama dan berdasarkan sudut pandang kebutuhan pelanggan.

Pendapat lain menjelaskan bahwa strategi adalah perencanaan induk yang komprehensif, yang menjelaskan bagaimana perusahaan akan mencapai semua tujuan yang telah di tetapkan berdasarkan misi yang telah di tetapkan sebelumnya (Rangkuti, 2013). Konsep strategi dapat di definisikan berdasarkan dua perspektif yang berbeda yaitu : (1) dari perspektif apa suatu organisasi ingin dilakukan (intens to do), dan (2) dari perspektif apa yang organisasi akhirnya lakukan (eventually does).

Dari definisi tersebut penulis menyimpulkan bahwa pengertian strategi adalah hal hal yang perusahaan ingin lakukan untuk mencapai suatu tujuan yang telah di tetapkan sebelumnya. Dalam buku Analisis SWOT Teknis Membedah Kasus Bisnis. Mengutip pendapat dari beberapa ahli mengenai strategi, diantaranya:

1. Chandler : Strategi merupakan alat untuk mencapai tujuan perusahaan dalam kaitannya dengan tujuan jangka panjang, program tindak lanjut, serta prioritas alokasi sumber daya.

2. Learned, Christensen, Andrews, dan Guth : Strategi merupakan alat untuk menciptakan keunggulan bersaing. Dengan demikian salah satu fokus strategi adalah memutuskan apakah bisnis tersebut harus ada atau tidak.

3. Argyris, Mintzberg, Steiner dan Miner : Strategi merupakan respons secara terus-menerus maupun adaptif terhadap peluang 
dan ancaman eksternal serta kekuatan dan kelemahan internal yang dapat memengaruhi organisasi.

4. Porter : Strategi adalah alat yang sangat penting untuk mencapai keunggulan bersaing.

5. Andrews, Chaffe : Strategi adalah kekuatan motivasi untuk stakeholders, seperti stakeholders, debtholders, manajer, karyawan, konsumen, komunitas, pemerintah, dan sebagainya, yang baik secara langsung maupun tidak langsung menerima keuntungan atau biaya yang ditimbulkan oleh semua tindakan yang dilakukan oleh perusahaan.

6. Hamel dan Prahalad : Strategi merupakan tindakan yang bersifat incremental (senantiasa meningkat) dan terus menerus dan dilakukan berdasarkan sudut pandang tentang apa yang diharapkan pelanggan di masa depan. Dengan demikian, perencanaan strategi hampir selalu dimulai dari "apa yang dapat terjadi", bukan dimulai dari “ apa yang terjadi”. Terjadinya kecepatan inovasi pasar baru dan perubahan pola konsumen memerlukan kompetensi inti (core competencies). Perusahaan perlu mencari kompetensi inti di dalam bisnis yang dilakukan (Rangkuti, 2013).

Dari definisi-definisi di atas maka dapat di simpulkan bahwa strategi adalah alat untuk mencapai tujuan atau keunggulan bersaing dengan melihat faktor eksternal dan internal perusahaan. Perusahaan melakukan tindakan yang dapat menjadikan keuntungan baik untuk perusahaan maupun pihak lain yang berada di bawah naungan perusahaan.

\section{Definisi Manajemen Strategis}

Pengertian manajemen strategis adalah sekumpulan keputusan dan tindakan yang merupakan hasil dari formula dan implementasi dari rencana yang telah didisain untuk mencapai tujuan perusahaan ${ }^{1}$. Manajemen strategi terdiri dari analisis, keputusan, dan aksi yang di ambil organisasi untuk menciptakan dan mempertahankan keunggulan kompetitif (Pearce II, Jhon A and Robinson Richard B, 2008).

Manajemen strategis adalah sekelompok keputusan dan tindakan manajerial yang menentukan kinerja jangka panjang organisasi ( $\mathrm{P}$. Robbins, 2008). Manajemen strategis penting karena dapat membuat perbedaan dalam seberapa baik kinerja suatu organisasi dan berhubungan dengan kenyataan bahwa organisasi dari semua jenis dan ukuran menghadapi situasi yang terus berubah.

Dari definisi tersebut, dapat di simpulkan bahwa pengertian dari manajemen strategis adalah serangkaian atau sekumpulan keputusan dan tindakan untuk menciptakan keunggulan kompetitif serta menentukan kinerja perusahaan dalam mencapai tujuan jangka panjang.

Manajemen strategis dapat di definisikan sebagai seni dan pengetahuan dalam merumuskan, mengimplementasikan, serta mengevaluasi keputusan-keputusan lintas fungsional yang memampukan sebuah organisasi mecapai tujuannya (David, 2011). Sebagaimana di 
siratkan oleh definisi ini, manajemen strategis berfokus pada usaha untuk mengintegrasikan manajemen, pemasaran, keuangan/akuntansi, produksi/operasi, penelitian dan pengembangan, serta sistem informasi komputer untuk mencapai keberhasilan organisasional. Jadi manajemen strategis adalah suatu perumusan atau tindakan yang berfokus pada tujuan manajemen di dalam perusahaan atau organisasi.

Manajemen strategis adalah serangkaian keputusan dan tindakan mendasar yang dibuat oleh manajemen puncak dan di implementasi oleh seluruh jajaran suatu organisasi dalam rangkai tujuan organisasi tersebut (Siagian, 2007). Manajemen strategis adalah seperangkat keputusan dan tindakan manajerial yang menentukan kinerja organisasi dalam jangka panjang. Manajemen strategis di definisikan sebagai kumpulan keputusan dan tindakan yang merupakan hasil dari rumusan dan implementasi pada rencana yang dibuat untuk mencapai tujuan perusahaan serta bagaimana mengevaluasi dan melaksanakan tindakan tersebut demi tercapainya tujuan organisasi, yang mencakup perumusan, implementasi dan evaluasi rencana strategi (Hubeis. M., 2008).

Dari definisi di atas dapat di simpulkan bahwa manajemen strategis adalah kumpulan keputusan dan tindakan manajerial yang dibuat manajemen puncak demi tercapai tujuan organisasi yang mencakup:

1. perumusan,

2. implementasi dan

3. evaluasi rencana strategi.

\section{Tahapan Manajemen Strategis}

Strategi yang baik dan tepat memiliki proses yang lebih terperinci.
Proses manajemen strategi terdiri atas tiga tahap: perumusan strategi, penerapan strategi, dan penilaian strategi. Tahapan tersebut, yaitu :

1. Perumusan Strategi Perumusan strategi terdiri dari:

- Pengembangan Visi dan Misi

- Identifikasi peluang dan ancaman eksternal suatu organisasi

- Kesadaran akan kekuatan dan kelemahan internal

- Penetapan tujuan jangka panjang

- Pencarian strategi-strategi aternatif

- Pemilihan strategi tertentu untuk mencapai tujuan (David, 2011).

Isu - isu perumusan strategi mencakup penentuan bis nis apa yang akan di masuki, bisnis apa yang tidak akan di jalankan, bagaimana mengalokasikan sumber daya, perlukah ekspansi atau diversifikasi operasi dilakukan, perlukah perusahaan terjun ke pasar internasional, perlukah mager atau penggabungan usaha dibuat, dan bagaimana menghindari pengambilalihan yang merugikan. Karena tidak ada organisasi yang memiliki sumber daya yang tak terbatas, para penyusun strategi harus memutuskan strategi alternatif mana yang akan paling menguntungkan perusahaan.

\section{Penerapan Strategi}

Pada tahap penerapan strategi mengharuskan perusahaan untuk menetapkan tujuan tahunan, membuat kebijakan, memotivasi karyawan, dan mengalokasikan sumber daya, sehingga strategi strategi yang telah di rumuskan dapat 
di jalankan. Tahap penerapan strategi terdiri dari :

- Pengembangan budaya yang suportif pada strategi

- Penciptaan struktur organisasional yang efektif

- $\quad$ Pengerahan ulang upaya-upaya pemasaran

- Penyiapan anggaran

- Pengembangan serta pemanfaatan sistem informasi

- Pengaitan kompensasi karyawan dengan kinerja organisasi

Sering kali dianggap sebagai tahap paling sulit dalam manajemen strategis, penerapan atau implementasi strategi membutuhkan disiplin, komitmen, dan pengorbanan personal. Penerapan strategi yang berhasil bergantung pada kemampuan manajer untuk memotivasi karyawan, yang lebih merupakan seni daripada pengetahuan. Strategi tersebut dirumuskan, namun bila tidak di terapkan tidak ada gunanya.

\section{Penilaian Strategi}

Penilaian strategi adalah tahap terakhir dalam manajemen strategis. Manajer mesti tahu kapan ketika strategi tertentu tidak berjalan dengan baik, penilaian atau evaluasi strategi merupakan cara utama untuk memperoleh informasi semacam ini. Tahap aktivitas penilaian strategi tediri dari :

- $\quad$ Peninjauan ulang faktor-faktor eksternal dan internal yang menjadi landasan bagi strategi saat ini

- $\quad$ Pengukuran kinerja

- $\quad$ Pengambilan langkah korektif

Penilaian strategi diperlukan karena apa yang berhasil saat ini tidak perlu berhasil nanti. Keberhasilan senantiasa menciptakan persoalan baru dan berbeda, organisasi yang mudah berpuas diri akan mengalami kegagalan.

\section{Pembangunan Daerah Tertinggal}

Daerah Tertinggal adalah daerah Kabupaten yang masyarakat serta wilayahnya relatif kurang berkembang dibandingkan daerah lain dalam skala nasional (Peraturan Bupati Pandeglang Nomor 27, 2016). penetapan kriteria daerah tertinggal dilakukan dengan menggunakan pendekatan berdasarkan pada perhitungan 6 kriteria dasar yaitu :

a. Perekonomian masyarakat, Yang diukur dengan indikator prosentase penduduk miskin dan kedalaman kemiskinan.

b. Sumberdaya manusia yang diukur dengan variabel ketenagakerjaan, kesehatan, dan pendidikan yang diukur dengan indikator prosentase penduduk menganggur, angka harapan hidup, angka melek huruf, angka partisipasi sekolah,

c. Ketersediaan infrastruktur, yang diukur dengan variabel keberadaan jalan, prosentase rumah tanggan pengguna risftik, prosentase rumah tangga pengguna telepon, air bersih, dan jumlah bank

d. Aksesibilitas, yang diukur dengan variabel rata-rata jarak pusat desa ke ibu kota kabupaten,

f. Kemampuan keuangan daerah, yang diukur dengan variabel celah kapasitas fiskal daerah, dan Karakteristik daerah, yang diukur dengan variabel prosentase bencana alam dan konflik sosial-politik. Pembangunan daerah tertinggal merupakan upaya 
terencana untuk mengubah suatu daerah yang dihuni oleh komunitas dengan berbagai permasalahan sosial ekonomi dan keterbatasan fisik, menjadi daerah yang maju dengan komunitas yang kualitas hidupnya sama atau tidak jauh tertinggal dibandingkan dengan masyarakat Indonesia lainnya.

Dalam hal ruang lingkup pelaksanaan pembangunan, pembangunan daerah tertinggal berbeda dengan penanggulangan kemiskinan karena dalam konteks ini selain aspek ekonomi dalam pembangunan dimaksud memasukkan pula aspek sosial, budaya, keamanan bahkan terkait dengan hubungan antar daerah tertinggal dengan daerah maju.

Prioritas, program, kegiatan, dan kebutuhan pembangunaan desa dirumuskan berdasarkan penilaian terhadap kebutuhan masyarakat desa yang meliputi:

a. Peningkatan kualitas dan akses terhadap pelayanan dasar;

b. Pembangunan dan pemeliharaan infrastruktur dan lingkungan berdasarkan kemampuan teknis dan sumberdaya lokal yang tersedia;

c. Pengembangan ekonomi pertanian berskala produktif;

d. Pengingkatan kualitas ketertiban dan ketentraman masyarakat desa berdasarkan kebutuhan masyarakat desa.

Pembangunan desa

dilaksanakan sesuai dengan Rencana Kerja Pemerintah Desa dengan melibatkan seluruh masyarakat desa dengan semangat gotong royong. Pelaksanaan pembanugnan desa dilakukan dengan memanfaatkan kearifan lokal dan sumber daya alam desa. Pembangunan lokal berskala desa dilaksanakan sendiri oleh desa.

\section{Pembahasan}

Kabupaten Pandeglang tahun 2019 tidak lagi menyandang predikat daerah tertinggal. Berdasarkan Keputusan Menteri Desa, Pembangunan Daerah Tertinggal, dan Transmigrasi Nomor 79 Tahun 2019 tentang Penetapan Kabupaten Daerah Tertinggal yang Terentaskan Tahun 2015-2019, Kabupaten Pandeglang masuk diantara 62 daerah yang terentaskan. Dalam keputusan tersebut, selain Kabupaten Pandeglang, daerah lain di Provinsi Banten yang juga terentaskan adalah Kabupaten Lebak.

\section{Perumusan Strategi Peningkatan Predikat Daerah Tertinggal}

Beberapa tahun terakhir, Kabupaten Pandeglang dan Kabupaten Lebak sulit melepaskan diri dari status daerah tertinggal, hal tersebut dikarenakan masyarakat dan wilayahnya relatif kurang berkembang dibandingkan daerah lain dalam skala nasional. Ketertinggalan daerah tersebut dapat diukur berdasarkan enam kriteria utama yaitu Ekonomi, Sumber Daya Manusia, Infrastruktur, Kapasitas Keuangan Daerah, Aksesibilitas dan Karakteristik Daerah.

Kabupaten Pandeglang masih memiliki puluhan desa dengan kategori tertinggal. Sehingga masih membutuhkan perhatian dari pemerintah pusat. Dengan ditetapkannya Kabupaten Pandeglang sebagai daerah yang terentaskan dari predikat tertinggal, maka menjadi tugas berat bagi pemerintah daerah dalam mengelola sumberdaya yang ada di daerah agar memiliki nilai ekonomi tinggi sehingga dapat mendiri dari bantuan pemerintah pusat maupun provinsi. 
Sejak tahun 2015 Kabupaten Pandeglang memiliki 75 desa tertinggal. Namun di tahun 2019 menyisakan 17 desa sebagai desa tertinggal sedangkan sisanya 12 desa akan ditingkatkan statusnya di tahun 2020. Meski sudah keluar dari daerah tertinggal, namun berdasarkan salinan surat keputusan yang ditandatangi oleh Menteri Desa PDT dan Transmigrasi, Eko Sandjojo itu, daerah tertinggal yang terentaskan masih mendapat pembinaan oleh kementerian atau lembaga dan Pemerintah Daerah Provinsi selama 3 tahun sejak ditetapkan sebagai daerah yang sudah terentaskan.

Strategi peningkatan predikat daerah tertinggal di Kabupaten Pandeglang tidak terlepas dari Laporan Sistem Akuntabikitas Kinerja Instansi Pemerintah (SAKIP) Pemkab Pandeglang tahun 2018 yang mendapatkan predikat B. Evaluasi penilaian SAKIP ini dilakukan oleh Kementerian Pendayagunaan Aparatur Negara dan Reformasi Birokrasi (Menpan-RB).

Bupati Kabupaten Pandeglang menyebutkan bahwa membaiknya SAKIP merupakan dampak dari efisiensi anggaran dan adanya integrasi antara perencanaan, penganggaran, pelaksanaan dan evaluasi proses Cascading. sekitar 150 program kegiatan yang berhasil dipangkas dalam rangka optimalisasi anggaran, sehingga kurang lebih dapat menghemat anggaran Rp. 40 Miliar.

Tahun $2016 \quad$ Kabupaten Pandeglang mendapatkan penilaian SAKIP dengan predikat CC, tahun 2017 naik menjadi B, dan tahun 2018 kenaikan predikat ditorehkan kembali menjadi BB. Kenaikan predikat ini bisa menjadi indikator jika Pemda Pandeglang berhasil dalam peningkatan penyelenggaraan pemerintah. Penilaian SAKIP Kabupaten Pandeglang dapat dilihat melalui tabel dibawah ini :

Tabel 5

Pernilaian SAKIP Kabupaten Pandeglang Tahun 2016-2018

\begin{tabular}{|c|c|c|}
\hline No & Tahun & Predikat \\
\hline 1 & 2016 & CC \\
\hline 2 & 2017 & B \\
\hline 3 & 2018 & BB \\
\hline \multicolumn{2}{|c|}{ Pencapaian } & tersebut
\end{tabular}

merupakan hasil kinerja dari seluruh Organisasi Perangkat Daerah (OPD) di Kabupaten Pandeglang. Seluruh OPD memiliki visi yang sama agar pelaksanaan program pemerintahan terus membaik, dan tujuannya tidak hanya penilaian saja, namun SAKIP merupakan kewajiban, karena laporan ini memang harus baik sehingga predikatnya dari masyarakat karena mendapat pelayanan terbaik. Selain itu, SAKIP juga memastikan penghematan anggaran, karena e-planning dan ebudgeting sudah terintegrasi. SAKIP dapat menyederhanakan laporan, dan pertanggung jawaban pemerintah daerah.

\section{Penerapan Strategi Peningkatan Daerah Tertinggal}

Strategi peningkatan predikat daerah tertinggal di Kabupaten Pandeglang tidak terlepas dari skema pengembangan ekonomi lokal yang di rancang oleh Kementerian Pedesaan dan Daerah Teringgal. Adapun pengembangan ekonomi lokal tersebut diantaranya adalah skema transportasi dari petani pelabuhan dan konsumen aksesnya dikembangkan dan dipercepat 
sehingga

meningkatkan

perekonomian desa, skema tersebut

\section{Gambar 1. Skema Transportasi Petani, Pelabuhan dan Konsumen}

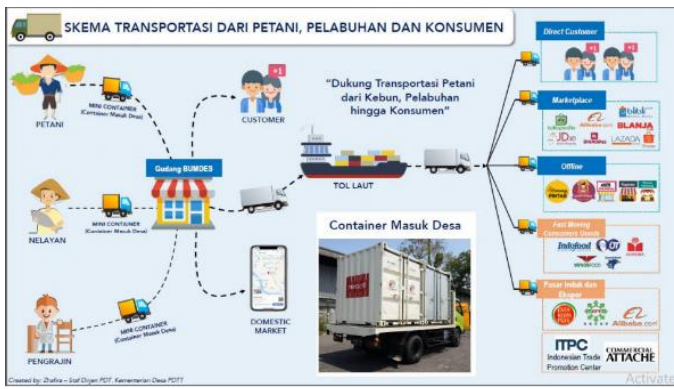

Selain skema lain yang direncanakan oleh Kementrian PDT dalam rangka meningkatkan predikat daerah tertinggal adalah penerapan smart farming yang dilakukan di setiap desa diberbagai daerah. Smart farming adalah penggabungan teknologi dalam peningkatan produksi hasil pertanian, perikanan dan peternakan di seluruh daerah tertinggal.

\section{Gambar 2. Penerapan Smart Farming}

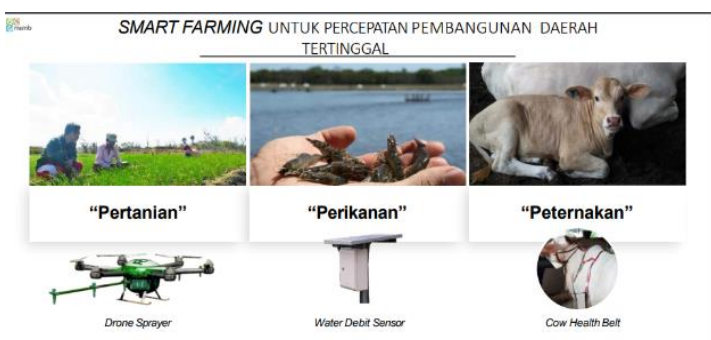

Selanjutnya adalah skema pendataan jumlah pohon buah di daerah tertinggal. Daerah tertinggal memiliki perkebunan buah namun banyak pohon buah yang ditanam di kebun-kebun rumah penduduk. Hal tersebut dapat meningkatkan skala ekonomi apabila dikonsolidasi melalui pendataan jumlah pohon buah dalam suatu kawasan serta waktu panen (untuk kebutuhan logistik dan tenaga kerja). Pendataan pohon dan sayu dapat menggunakan teknologi Artificial Intelegence Drone Surveillance.

\section{Gambar 3. Pendataan Jumlah Pohon Buah}

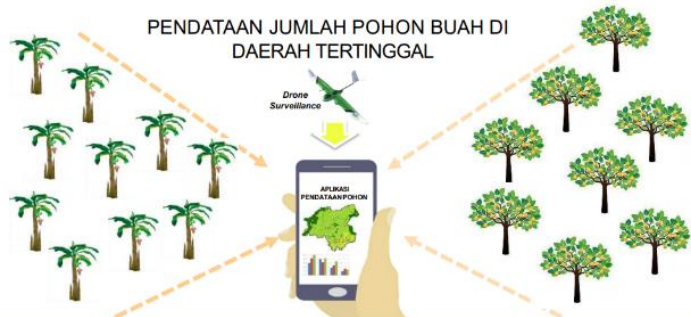

\section{Penilaian Strategi}

Berdasarkan strategi dan beberapa upaya yang telah dilakukan oleh Pemerintah Kabupaten Pandeglang dalam rangka upaya peningkatan Predikat Daerah Tertinggal akhirnya membuahkan hasil positif. Presiden Joko Widodo (Jokowi) mengesahkan Peraturan Presiden (Perpres) Nomor 63 Tahun 2020 tentang penetapan daerah tertinggal tahun 2020-2024.

Terdapat 62 daerah yang ditetapkan tertinggal. Daerah tertinggal tersebut adalah daerah kabupaten yang wilayah serta masyarakatnya kurang berkembang dibandingkan dengan daerah lain dalam skala nasional.

Berdasarkan Perpres tersebut kabupaten Pandeglang tidak termasuk 62 daerah yang ditetapkan sebagai daerah tertinggal. Upaya strategi yang telah dilakukan memberikan hasil positif pada penilaian predikat daerah tertinggal di Indonesia tahun 2020-2024. Upaya strategi Kabupaten Pandeglang dinilai efektitf dalam menekan kriteria yang telah ditetapkan dalam peraturan daerah tertinggal. Berdasarkan hal itu maka di Provinsi Banten sudah tidak ada lagi 
kabupaten yang termasuk dalam predikat daerah tertinggal. Hal ini menjadi bahan rekomendasi bagi provinsi lain di Indonesia yang masih dalam predikat daerah tertinggal.

\section{Kesimpulan}

Tahun 2015 kabupaten ditetapkan sebagai daerah dengan predikat daerah tertinggal, hal tersebut membuat pemerintah daerah berfikir keras untuk meningkatkan predikat terserbut. Beberapa perbaikan diberbagai sektor telah dilakukan salah satunya melakukan strategi efisiensi penggunaan anggaran melalui pemangkasan beberapa program yang dampaknya terhadap peningkatan kenaikan penilaian SAKIP setiap tahunnya. Strategi tersebut membuahkan hasil dengan peningkatan penilaian SAKIP yang dampaknya terhadap peningkatan predikat daerah tertinggal. Selain itu Kabupaten Pandeglang juga telah melakukan skema pengembangan ekonomi dalam meningkatkan predikat daerah tertinggal melalui skema yang digagas Kementerian PDT yaitu dengan Transportasi dari Petani, Pelabuhan dan Konsumen, Skema Smart Farming, dan Skema Pendataan jumlah pohon buah di daerah tertinggal.

\section{Referensi}

David, F. (2011). Strategic Management, Manajemen Strategi Konsep. Salemba Empat.

Hubeis. M., N. (2008). Manajemen Strategik dalam Pengembangan Daya Saing Organisasi. Elex Media Komputindo.

P. Robbins, S. (2008). Organizational Behaviour, Tenth Edition
(Perilaku Organisasi Edisi

Kesepuluh) (Macanan Jaya

Cemerlang (ed.)).

Pearce II, Jhon A and Robinson Richard B, J. (2008). Manajemen Strategis. Salemba Empat.

Peraturan Bupati Pandeglang Nomor 27. (2016). Peraturan Bupati Pandeglang.

Peraturan Presiden RI Nomor 131. (2015). No Title.

Rangkuti, F. (2013). Analisis SWOT: Teknik Membedah Kasus Bisnis (Gramedia Pustaka (ed.)).

Siagian, S. (2007). Manajemen Sumberdaya Manusia (Bumi Aksara (ed.)).

\section{Internet}

www.kominfo.go.id. (2019). No Title. Www.Kominfo.Go.Id/Content/D etail/9545/Melalui-NawacitaPemerintah-BerkomitmenBangun-Desa/0/Berita. www.kominfo.go.id/content/det ail/9545/melalui-nawacitapemerintah-berkomitmenbangun-desa/0/berita

www.pelitabanten.com. (n.d.). No Title.

Https://Www.Pelitabanten.Com /26977/2018/05/09/MasihBerstatus-Daerah-TertinggalBupati-Pandeglang-MintaPerhatian-Khusus-DariPemprov-Banten. https://www.pelitabanten.com/ 26977/2018/05/09/masihberstatus-daerah-tertinggalbupati-pandeglang-mintaperhatian-khusus-dari-pemprovbanten 